\title{
Study on the Effect of Casting Pressure on the Wear Resistance of Al-Si Alloy Prepared by Squeeze Casting
}

\author{
Muna Khedier Abbass and Osama Sultan Muhammed \\ Dept. of Production Engineering and Metallurgy and Dept. of Materials \\ Engineering, University of Technology, Baghdad, Iraq \\ mukeab2005@yahoo.com\&oalaamiri@yahoo.com
}

\begin{abstract}
In this research the effect of applied casting pressure at constant pouring and die preheating temperatures on the microstructure and wear resistance of the squeeze cast Al-Si alloy was investigated. The results showed a refinement in the microstructure with increasing of the squeeze pressure. The results also showed that the density of the specimens decreased with application of a $7.5 \mathrm{MPa}$ applied pressure, but it increased steadily for higher pressures up to 53 $\mathrm{MPa}$. Increasing the squeeze pressure resulted in increasing the hardness and decreasing the wear rate. These results were explained based on the densification mechanism brought about by the application of pressure during solidification.
\end{abstract}

Keywords: Squeeze casting, Wear resistance, Al-Si alloy.

\section{Introduction}

Squeeze casting has been used for half a century in Russia and is now being exploited in the west. For example, Toyota Motor Company in Japan introduced squeeze cast aluminum alloys wheels into their product line for passenger cars in $1979^{[1]}$. The aluminum alloy 357 (Al-7Si$0.5 \mathrm{Mg}$ ) was prepared by sand, gravity die and squeeze casting, the properties of the alloy show to be clearly superior. The improvement in ductility is particularly notable ${ }^{[2,3]}$. The commercial development of squeeze casting began to take place in Europe, North America and Japan only after 1960 as reported by Dorcic and Verma ${ }^{[4]}$. 
Squeeze casting permanent mold is frequently used to produce safely critical aluminum suspension components. Squeeze cast aluminum components have replaced iron/steel control arms and front knuckles in volume recently. In late 1994, Delphi Chassis System and Casting Technology Company began a joint development program for an aluminum front knuckle conversion slated for application on mainstream passenger cast ${ }^{[5]}$. Squeeze casting was selected based on the superior physical and mechanical properties, dimensional capabilities and integrated process controls. Davidson et al. ${ }^{[6]}$ studied fatigue properties for squeeze, semisolid and gravity die casting, fatigue cracks initiated from oxide defects in the squeeze cast castings of Al-7Si-xMg alloys and from both oxide defects and shrinkage pores in semisolid and gravity castings. Despite differences in the microstructures and in the defect populations in the squeeze and semisolid casting, their fatigue properties were similar.

Cay and $\mathrm{Kurnaz}^{[7]}$ studied the tensile and fatigue properties of Zinc-Aluminum (ZA-8, ZA-12, ZA-27) in squeeze and gravity cast forms. The squeeze cast alloys exhibited good fatigue resistance in proportion to the gravity castings.

Squeeze casting, also known as liquid metal forging, is a combination of casting and forging process ${ }^{[8,9]}$. The molten metal is poured into the bottom half of the pre-heated die. As the metal starts solidifying, the upper half closes the die and applies pressure during the solidification process. The amount of pressure thus applied is significantly less than used in forging, and parts of great detail can be produced. Coring can be used with this process to form holes and recesses. The porosity is low and the mechanical properties are improved $^{[10,11]}$.

The aims of the present work is to study the effect of casting pressure or applied pressure at constant pouring and die preheating temperatures on microstructure and wear resistance of squeeze cast samples and comparing it with those of gravity die casting.

\section{Experimental Work}

\subsection{Materials}

The Al-Si alloy (AlSi12) was selected since it has very good castability and excellent weldability, because of its eutectic composition 
and low melting point of $570^{\circ} \mathrm{C}$. The alloy is particularly suitable for intricate, thin walled, leak-proof fatigue resistant casting and good corrosion resistance ${ }^{[12]}$.

\subsection{Gravity Die Casting}

The Al-12\% Si alloy was melted and poured in die or metallic mold by gravity casting. For each experiment about 200 gm of prealloyed (Al$12 \% \mathrm{Si}$ ) is put in graphite crucible in an electric furnace at temperature $700^{\circ} \mathrm{C}$. The melt was poured into a metallic mold which was hot dried before casting operation at $200^{\circ} \mathrm{C}$ by using drier type (Heracus). The casting was left to cool down in the air. The specimens of prepared alloy had dimensions of $100 \mathrm{~mm}$ length, $15 \mathrm{~mm}$ in width and $30 \mathrm{~mm}$ in height. Table 1 shows the chemical composition of the (Al-Si) alloy.

Table 1. Chemical composition of the DIN1725 (Al-Si) alloy.

\begin{tabular}{|c|c|c|c|c|c|c|c|c|}
\hline Element & $\mathrm{Si}$ & $\mathrm{Fe}$ & $\mathrm{Cu}$ & $\mathrm{Mn}$ & $\mathrm{Mg}$ & $\mathrm{Zn}$ & $\mathrm{Ti}$ & $\mathrm{Al}$ \\
\hline $\mathbf{W t} \%$ & 12.1 & 0.65 & 0.83 & 0.2 & 0.27 & 0.45 & 0.02 & Remainder \\
\hline
\end{tabular}

\subsection{Squeeze Casting System}

\subsubsection{Hydraulic Press}

Figure 1 shows the hydraulic press with a hydraulic pump. A vertical hydraulic press is used (with a ram $70 \mathrm{~mm}$ in diameter) to apply the pressure in a perpendicular direction to the squeeze casting die. The press can apply a hydraulic pressure of (1-70) $\mathrm{Kg} / \mathrm{cm}^{2}$, with a constant ram speed of $25 \mathrm{~cm} / \mathrm{min}$.

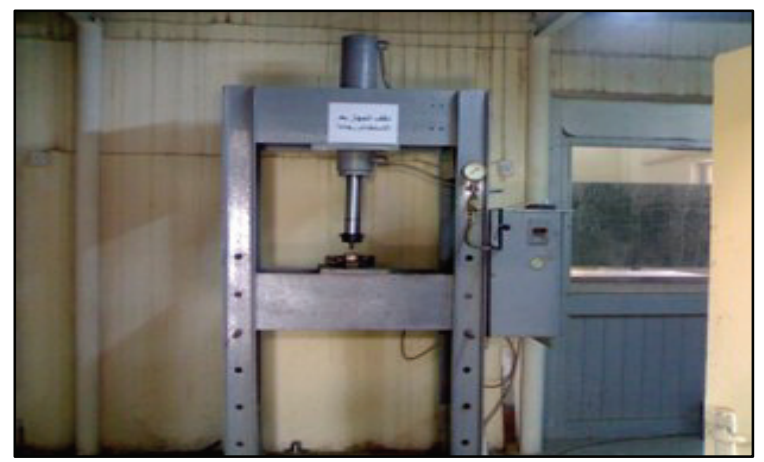

Fig. 1. The hydraulic press.

\subsubsection{Squeeze Punch}

The selected squeeze punch shown in Fig. 2(a,b) was made of low alloy steel, and designed with a hole in its upper part to be fixed to the 
ram with two steel bolts. The lower part of the punch is rectangular in shape with a semicircle ends. This lower part is used to squeeze the molten alloy.

\subsubsection{Squeeze Die}

Figures 2(a,c) show the squeeze die. The die is horizontal, made of low alloy steel and consists of two parts joined by four high temperature resistant steel bolts. This design allows the final squeezed composite casting to be removed from the die easily.

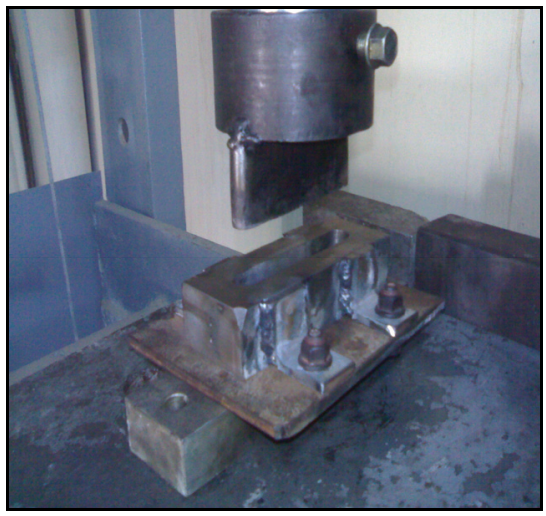

Fig. 2(a). The punch and the die on the press.

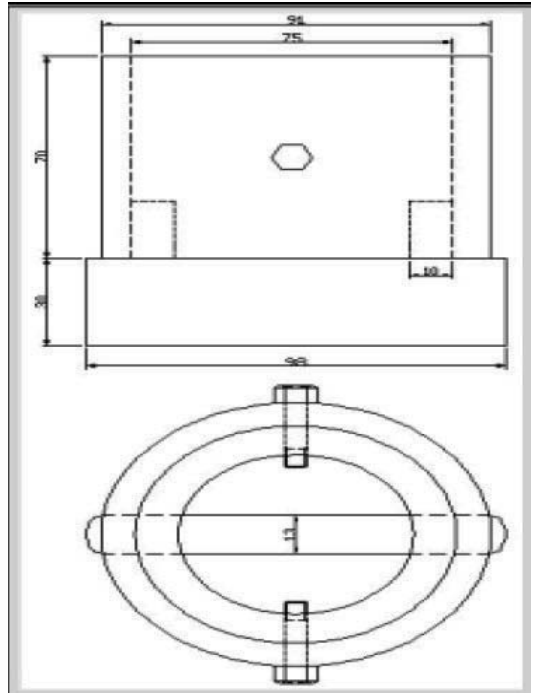

(b)

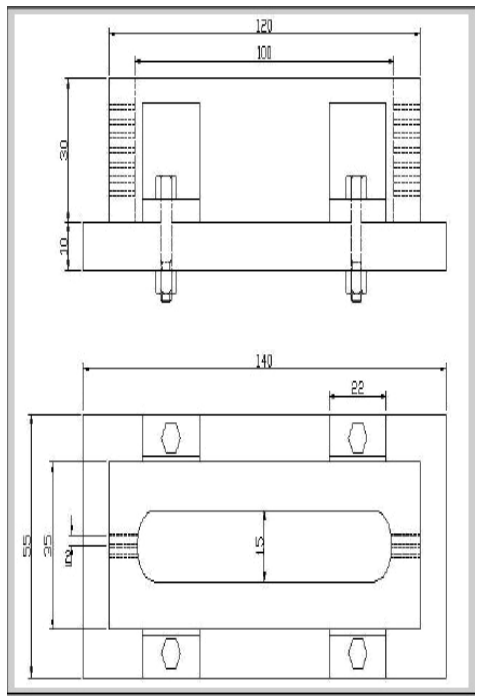

(c)

Fig. 2 (b,c). Schematic diagrams of the squeeze punch and the die (mm). 
Figures $2(a, b, c)$ show the punch and the die on the press table. Table 2 illustrates the chemical composition of the punch and the die material which was done with the portable metals analyzer type 1650 from the ARUN Technology, Germany.

Table 2. Chemical composition of the punch and die steel.

\begin{tabular}{|c|c|c|c|}
\hline Element & Weight Percent (\%) & Element & Weight Percent (\%) \\
\hline $\mathrm{Fe}$ & 93.9 & $\mathrm{Co}$ & 0.02 \\
\hline $\mathrm{C}$ & 1.0 & $\mathrm{Cu}$ & 0.585 \\
\hline $\mathrm{Cr}$ & 2.84 & $\mathrm{Mo}$ & 0.0599 \\
\hline $\mathrm{Ni}$ & 0.936 & $\mathrm{Nb}$ & 0.01 \\
\hline $\mathrm{Si}$ & 0.227 & $\mathrm{Ti}$ & 0.02 \\
\hline $\mathrm{Mn}$ & 0.383 & $\mathrm{~V}$ & 0.02 \\
\hline $\mathrm{Al}$ & 0.0253 & $\mathrm{Sn}$ & 0.04 \\
\hline
\end{tabular}

\subsubsection{Squeeze Casting}

The Al-Si alloy is melted in an electric furnace at the required weight and temperature using an alumina crucible. The next step is preheating the squeeze casting die to the required preheating temperatures $200^{\circ} \mathrm{C}$ and placing the die on the table of the hydraulic press. After that checking all required temperatures with digitally calibrated thermocouples and then pouring the molten Al-Si alloy into the die cavity. The pouring temperature that is used for all castings is $700^{\circ} \mathrm{C}$. The final step is the application of the required squeeze pressure for 30 seconds at a delay time of 5 seconds and allowing for solidification. The casting pressures that were used for all castings are $(7.5,23,38,53) \mathrm{MPa}$, then removing the solidified casting from the die.

\subsection{Tests and Measurements}

\subsubsection{Microstructure and Hardness Test}

A small specimen of alloy ( $\mathrm{Al}-12 \% \mathrm{Ci})$, (alloy A) and squeeze cast samples (B,C,D and E) were prepared by turning processes in the dimensions of $100 \mathrm{~mm}$ length and $15 \mathrm{~mm}$ width. Wet grinding operation with water was done by using emery paper of $\mathrm{SiC}$ with the different grits $(220,320,500$, and 1000). Polishing process was done to the specimens by using diamond paste of size $(1 \mu \mathrm{m})$ with special polishing cloth and lubricant in order to get $1 \mu \mathrm{m}$ surface roughness. They were cleaned with water and alcohol and dried with hot air. Etching process was done to the specimens by using etching solution which is composed of $(99 \%$ $\left.\mathrm{H}_{2} \mathrm{O}+1 \% \mathrm{HF}\right)$, then the specimens were washed with water and alcohol 
and dried. Vickers hardness test was made by using Vickers hardness tester type (Einsingenbei U/M, Mode Z323). Diamond indenter was forced into the surface of the specimen being tested under a static load of (300 mg) for (15) sec. Measurements of the indentation diameter were made in (3-5) readings and the average hardness (VHN) was found.

\subsubsection{Density and Porosity Measurements}

The weight of squeeze cast samples were measured in air by using sensitive balance type (Denver - max $210 \mathrm{gm}$ ) with an accuracy of $0.0001 \mathrm{mg}$. The volume of cylindrical sample of $20 \mathrm{~mm}$ length and 10 $\mathrm{mm}$ diameter was calculated. The actual density $\left(\rho_{\mathrm{ac}}\right)$ can be found from the following equation:

$$
\rho a c=\frac{\text { weight }}{\text { volume }}
$$

Where:

$\rho_{\mathrm{ac}}=$ actual density

The porosity percentage $(\mathrm{P} \%)$ was measured for the squeeze cast samples by using both the actual density $\left(\rho_{\mathrm{ac}}\right)$ and theoretical density of reference alloy $\left(\rho_{\mathrm{th}}\right)$, using equation as follows ${ }^{[13]}$ :

$$
P \%=1-\frac{\rho a c}{\rho t h}
$$

Where:

$\mathrm{P} \%=$ porosity percentage

$\rho_{\mathrm{ac}}=$ actual density

$\rho_{\mathrm{th}}=$ theoretical density

\subsubsection{Wear Test}

Wear specimens were machined from ingot and cut according to ASTM specification D2625-83 of $20 \mathrm{~mm}$ length and $10 \mathrm{~mm}$ diameter ${ }^{[14]}$. Then one surface of each specimen was ground and polished to obtain clean and smooth surface. The initial surface roughness of the wear specimens was $\mathrm{Ra}=0.20 \mu \mathrm{m}$.

\subsubsection{Wear Apparatus}

A Pin-On-Disc wear apparatus was used, which was designed according to ASTM specification F732-82 ${ }^{[14]}$. The wear apparatus consists of motor with constant revolution speed of (510 rpm). 


\subsubsection{Wear Rate Measurement}

Weight method was used to determine the wear rate of specimens. The specimens were weighed before and after the wear test by sensitive balance type (DENVER instrument, Max-210gm) with accuracy of $0.0001 \mathrm{gm}$. The weight loss $(\Delta \mathrm{W})$ was divided by the sliding distance and the wear rate was obtained by using equation as follows ${ }^{[15]}$.

$$
\begin{gathered}
\text { Wear rate }=\Delta \mathrm{w} / \mathrm{S}_{\mathrm{D}} \\
\Delta \mathrm{w}=\mathrm{w}_{2}-\mathrm{w}_{1} \\
\mathrm{~S}_{\mathrm{D}}=\mathrm{S}_{\mathrm{S}} * \mathrm{t} \\
\text { Wear rate }(\mathrm{Wr})=\Delta \mathrm{W} / \pi \mathrm{D} \rho \mathrm{Nt}
\end{gathered}
$$

Where:

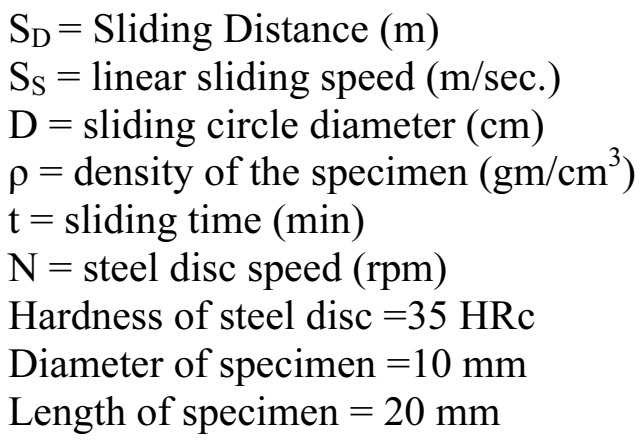

\section{Results and Discussion}

\subsection{Hardness and Microstructure Results}

Vickers hardness results are given in Table 3. It is seen that the squeeze cast samples have higher hardness values than that of gravity die cast sample. This is due to rapid solidification and high cooling rate of molten metal under applied pressure which gives smaller grain size and finer eutectic phase (Al-Si) than that of gravity die cast. Figure 3 shows the microstructure of gravity cast sample (A) which consists of primary phase $(\alpha-\mathrm{Al})$ and dark gray color of silicon phase (As flakes). A part of silicon phase is shown as massive silicon (Grey color) in some regions of matrix microstructure. As applied pressure increases, the refinement of eutectic phase increases and in comparison with squeeze cast technique, the $\alpha$-dendrites were much bigger and dendrite structure forms as shown in Fig. (4-7) for squeeze cast samples (B, C, D and E) respectively. 
Figure 8 shows the effect of casting pressure on the Vickers hardness number $(\mathrm{VHN})$ of the different alloys. The hardness values increase from $82 \mathrm{HV}$ to $118 \mathrm{HV}$ at pressures $7.5 \mathrm{MPa}$ to $53 \mathrm{MPa}$ respectively. It was explained that the microstructural changes played an important role in the increase of hardness value of the squeeze castings.

Table 3. The Actual density, theoretical density, VHN and P\%, determination for squeeze castings under different applied pressures.

\begin{tabular}{|c|c|c|c|c|c|c|c|}
\hline Sample & $\begin{array}{c}\mathbf{P}^{*} \\
\mathbf{M P a}\end{array}$ & $\begin{array}{c}\mathbf{T}^{*} \\
{ }^{\circ} \mathbf{C}\end{array}$ & $\begin{array}{c}\mathbf{T d}^{*} \\
{ }^{\mathbf{O}} \mathbf{C}\end{array}$ & $\begin{array}{c}\boldsymbol{\rho}_{\mathbf{a c}} \\
\mathbf{g} / \mathbf{c m}^{\mathbf{3}}\end{array}$ & $\begin{array}{c}\boldsymbol{\rho}_{\text {th }} \\
\mathbf{g} / \mathbf{c m}^{\mathbf{3}}\end{array}$ & $\mathbf{P \%}$ & $\mathbf{V H N}$ \\
\hline A & $\begin{array}{c}\text { Gravity Die } \\
\text { Casting }\end{array}$ & 700 & 200 & - & 2.68 & - & 69 \\
\hline B & 7.5 & 700 & 200 & 2.675 & 2.68 & 0.2 & 82 \\
\hline C & 23 & 700 & 200 & 2.59 & 2.68 & 3.4 & 96 \\
\hline D & 38 & 700 & 200 & 2.619 & 2.68 & 2.27 & 106 \\
\hline E & 53 & 700 & 200 & 2.674 & 2.68 & 0.22 & 118 \\
\hline
\end{tabular}

${ }^{*} \boldsymbol{\rho}_{\mathbf{a c}}$ : Actual density $\left(\mathrm{g} / \mathrm{cm}^{3}\right), \mathbf{T p}$ : Pouring temperature $\left({ }^{\circ} \mathrm{C}\right), \boldsymbol{\rho}_{\text {th }}$ : Theoretical density $\left(\mathrm{g} / \mathrm{cm}^{3}\right), \mathbf{T d}:$ Die (Mold) temperature $\left({ }^{\circ} \mathrm{C}\right), \mathbf{P} \%$ : Porosity percentage, Pa : Applied pressure MPa, VHN: Vickers Hardness Number

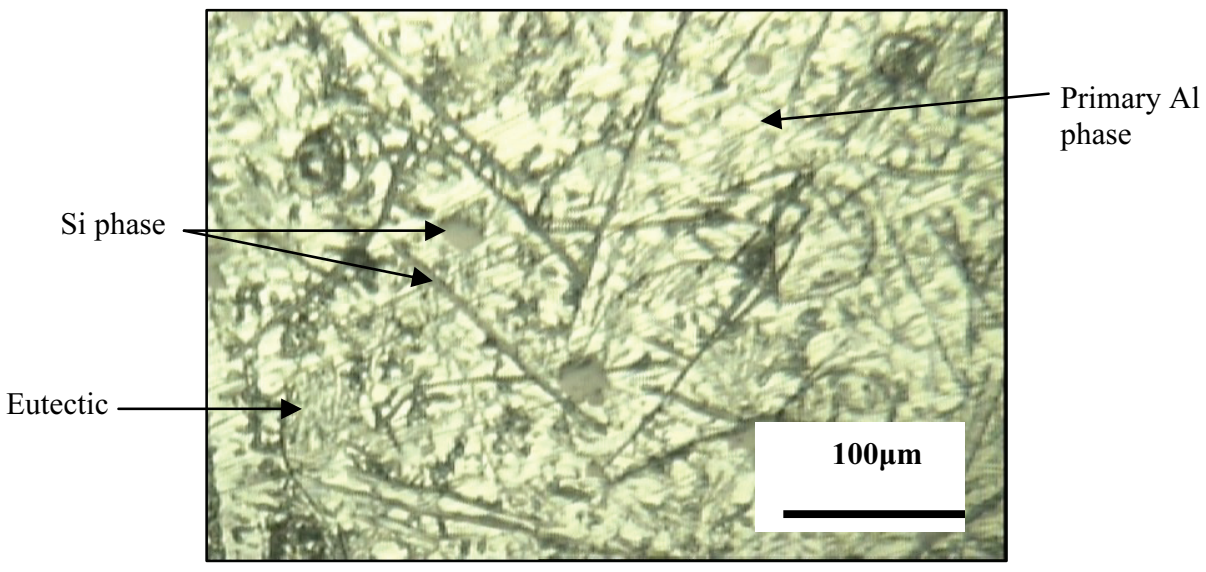

Fig. 3. Microstructure of gravity die cast sample A: without pressure.

\subsection{Density and Porosity Measurements Results}

The effect of squeeze pressure on density and porosity are illustrated in Table 3. Although the density is expected to increase continuously with increasing the applied pressure of squeeze casting, it shows a drop at the minimum used pressure of $7.5 \mathrm{MPa}$. This is attributed to the existence and segregation of porosities at the center of sample. The main part of shrinkage for the samples solidified under atmospheric pressure has been accommodated by formation of a large shrinkage pipe 
on the top surface of cast. Upon the application of squeeze pressure, such shrinkage pipe and cavities are pushed down toward the bulk of the samples. Consequently, if the applied pressure is not large enough to eliminate such cavities, smaller density values may be attained. With further increase in the applied pressure up to $53 \mathrm{MPa}$, gas and shrinkage porosities decrease and hence density increases. These results are in agreement with those of other researchers ${ }^{[16,17,18]}$.

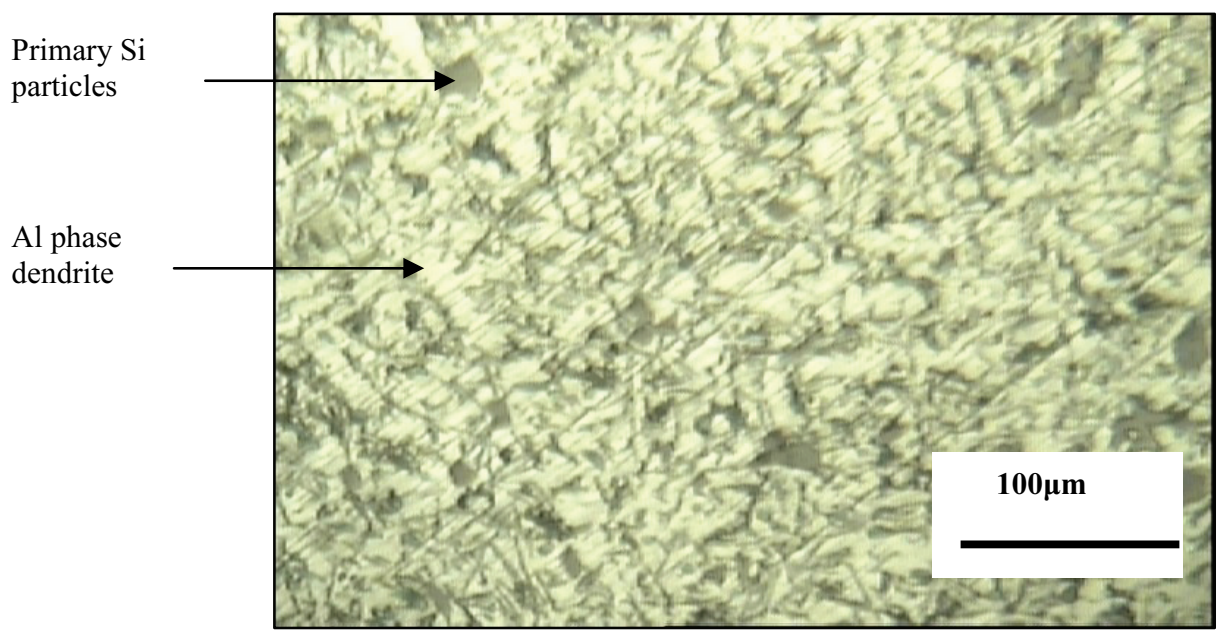

Fig. 4. Microstructure of squeeze cast sample $B$ : at $P=7.5 \mathrm{MPa}$.

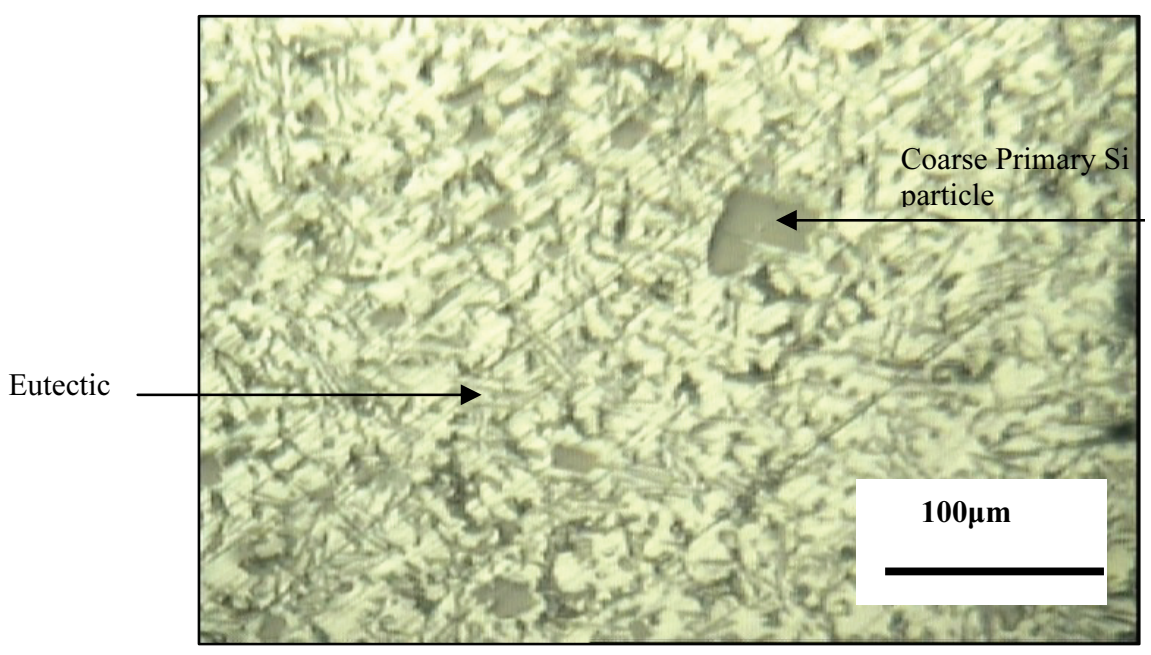

Fig. 5. Microstructure of squeeze cast sample $C$ : at $\mathbf{P}=\mathbf{2 3 M P a}$. 
Fine Eutectic

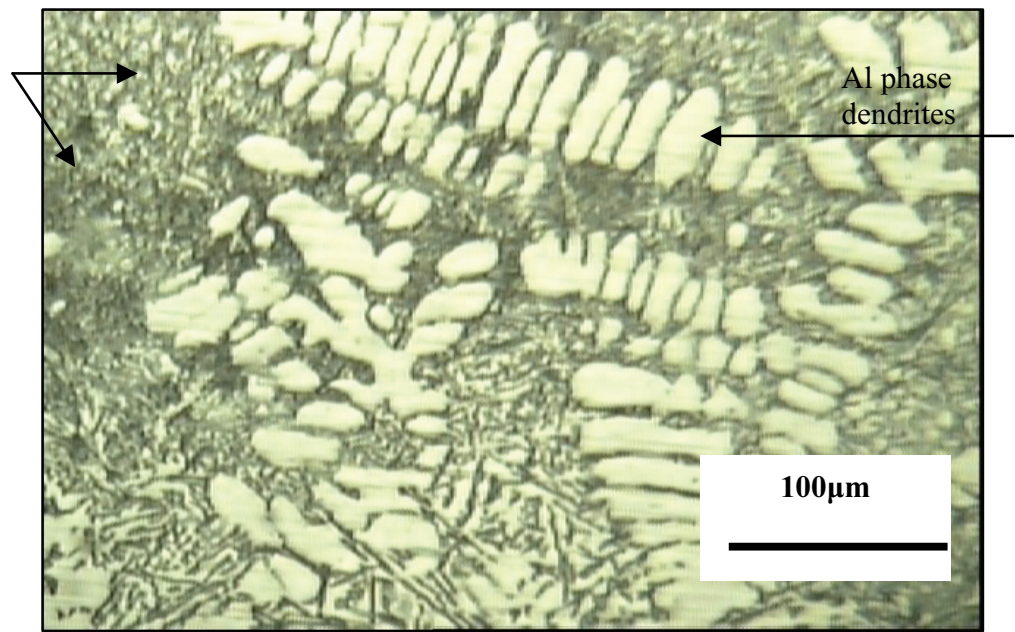

Fig. 6. Microstructure of squeeze cast sample $D$ : at $P=38 M P a$.

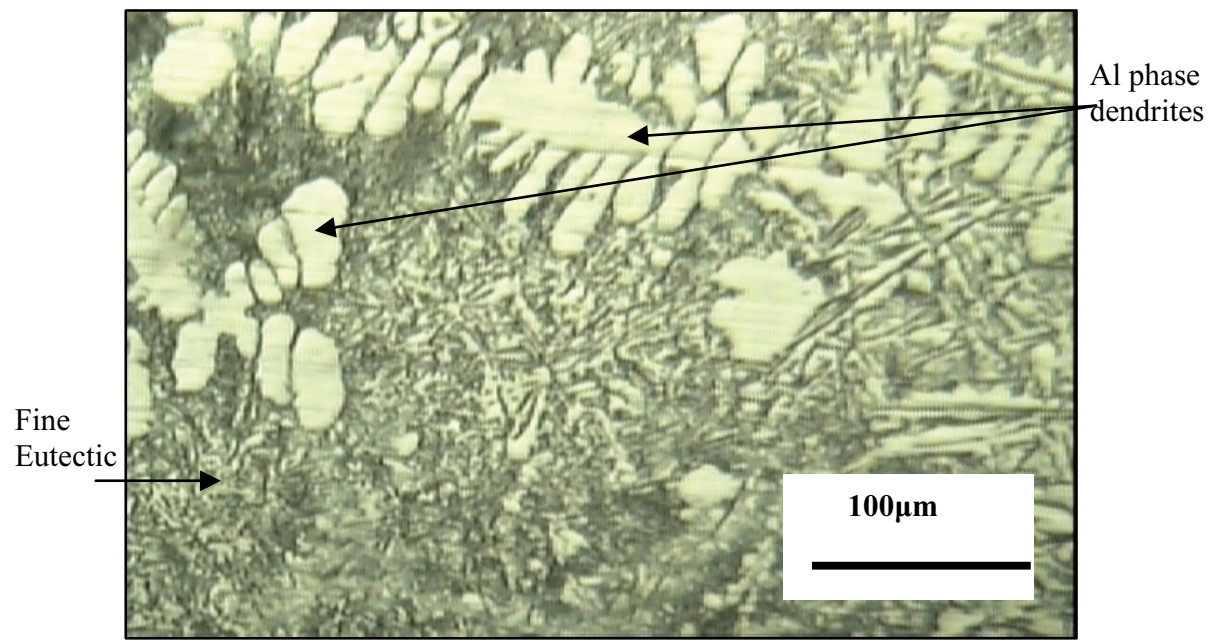

Fig. 7. Microstructure of squeeze cast sample $E$ : at $P=53 \mathrm{MPa}$.

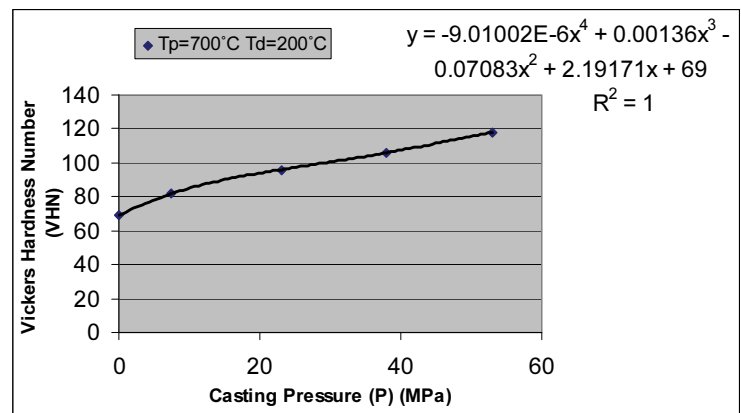

Fig. 8. Effect of the squeeze casting pressure on Vickers hardness number of different alloys. 


\subsection{Wear Rate Results}

Figure 9 shows the effect of applied pressure on the wear rate of different samples (A, B, C, D and E) under dry sliding conditions at a load of $20 \mathrm{~N}$, sliding time of $20 \mathrm{~min}$ and sliding speed of $2.7 \mathrm{~m} / \mathrm{sec}$. The wear rate reduces or the wear resistance increases with increasing the applied pressure that was used to press the molten alloy in the die cavity during squeeze casting of alloy ( $\mathrm{Al}-12 \% \mathrm{Si})$. This is due to increase in the hardness value and more refinement of the microstructure as the applied pressure increases because of the reduction of shrinkage porosity as a result of bulk deformation and improving of filtration feeding action during solidification under pressure in squeeze casting ${ }^{[19]}$.

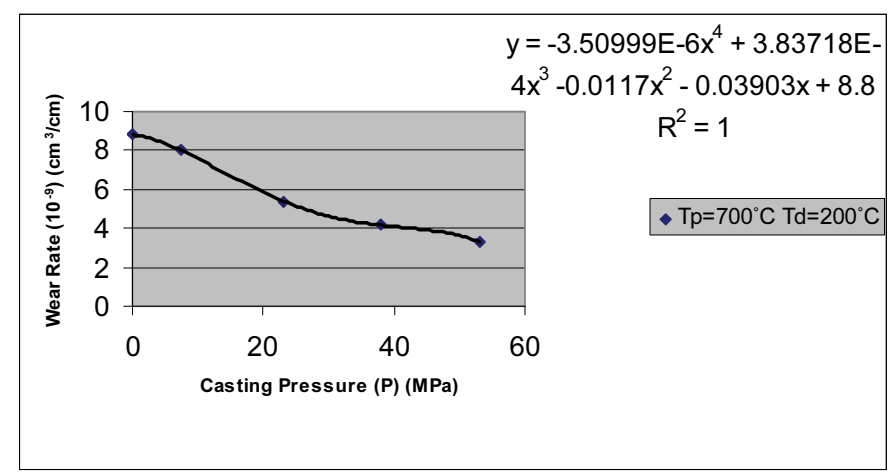

Fig. 9. Effect of the squeeze casting pressure on wear rate of alloy $(\mathrm{Al}-12 \% \mathrm{Si})$ at a sliding speed of $2.7 \mathrm{~m} / \mathrm{sec}$, applied load in wear test of $20 \mathrm{~N}$ and sliding time of $20 \mathrm{~min}$.

Figure 10 (a, b, c, d and e) shows micrographs of the worn surfaces of the cast samples (A, B, C, D and E) respectively at a sliding speed of $2.7 \mathrm{~m} / \mathrm{sec}$ and a load of $20 \mathrm{~N}$, and for sliding time of 20 min during wear test. The worn or damaged surfaces show continuous grooves and cracking of long wear track. In some places, some plastic deformation, together with presence of fine oxides debris particles are also observed in case of gravity die cast sample. While it is seen a smooth and glassy finish and faint wear lines in the direction of sliding on worn surfaces, which indicates a mild abrasion wear mode is present in the case of the samples which were squeeze cast at an applied pressure of (53 MPa).

\section{Conclusions}

- The microstructure examination showed that small grain size and refine eutectic phase morphologies had been obtained in squeeze casting with respect to gravity die casting. 

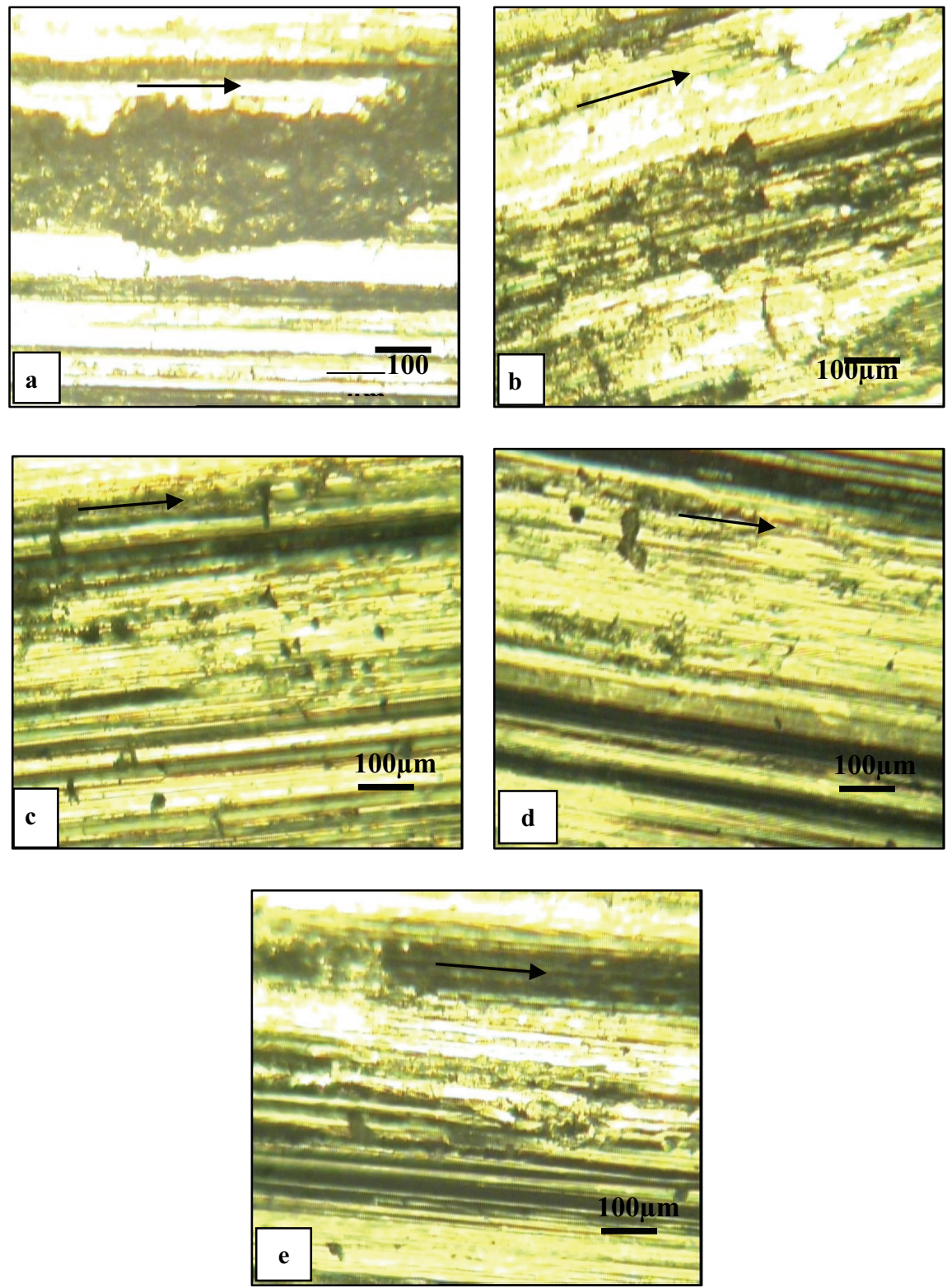

Fig. 10. Micrographs of the worn surfaces of the alloy (Al-!2\%Si) at a sliding speed of 2.7 $\mathrm{m} / \mathrm{sec}$ and a load of $20 \mathrm{~N}$, sliding time of $20 \mathrm{~min}$, Sliding direction:

(a) Gravity die cast sample

(b) Squeeze cast sample at applied pressure 7.5 MPa

(c) Squeeze cast sample at applied pressure $23 \mathrm{MPa}$

(d) Squeeze cast sample at applied pressure $38 \mathrm{MPa}$

(e) Squeeze cast sample at applied pressure $53 \mathrm{MPa}$ 
- The samples were produced by squeeze casting technique had higher Vickers hardness values and wear resistance than that of the gravity die technique.

- As the applied pressure for squeeze cast samples increases the hardness value increases up to $118 \mathrm{VHN}$ at a squeeze pressure of (53 $\mathrm{MPa}$ ) when compared to that of the gravity cast sample which was 69 VHN.

- The actual density of squeeze samples was improved and reached $2.67 \mathrm{gm} / \mathrm{cm}^{3}$ and approached the theoretical density which was 2.68 $\mathrm{gm} / \mathrm{cm}^{3}$, because of the reduction in shrinkage porosity as applied pressure increases during solidification in squeeze casting.

- Faint wear lines in the direction of sliding on worn surfaces indicate that a mild abrasion wear mode is presented for squeeze cast samples which was produced at higher applied pressure. That means a higher wear resistance was obtained.

\section{References}

[1] Polmear, I.J., "Light Alloys, Metallurgy of the Light Metals", $2^{\text {nd }}$ Edition, Edward Arnold, Great Britain (1989).

[2] Lavington, M.H., "Mechanical Properties of 357 Aluminum Alloy produced By Different Casting Processes", Metals and Materials, 2: 713 (1986).

[3] Chadwick, G.A., "Tensile Properties of Squeeze Cast Alloy 7010 as a Function Squeezing Pressure", Metals and Materials, 2: 693(1986).

[4] Dorcic, J.L. and Verma, S.K., "Squeeze Casting", Metals Handbook, $9^{\text {th }}$ Edition (1990).

[5] Bonollo, F., "Squeeze Casting, An Advanced Process", Aluplanet Daily, www.aluplanet.com.

[6] Davidson, C.J., Griffiths and J.R., Zanada, A., "Fatigue Properties of Squeeze, Semisolid and Gravity Die Cast Al-Si-Mg Alloy", SIF2004, Structural Integrity and Fracture. http:// eprint.uq.edu.au./archive/0000836.

[7] Cay, F. and Kurnaz, S.C., "Hot Tensile and Fatigue Behavior of Zinc-Aluminum Alloys Produced by Gravity and Squeeze casting", Materials and Design, 26: 479-485 (2005).

[8] Davis, J.R., "Casting", Metals Handbook, Second Edition, part 3 (1998).

[9] Vijian, P. and Arunachalam, V.P., "Modelling and multi objective optimization of LM24 aluminum alloy squeeze cast process parameters using genetic algorithm", J. Mat. Proc. Tech., 186: 82-86 (2007).

[10] Renyi Casting Machinery,"Sand Casting", Sand Castings Journal, 27:Nov. (2007).

[11] Yue, T.M., "Squeeze casting of high-strength aluminum wrought alloy AA7010", J. Mat. Proc. Tech., 66: 179-185 (1997).

[12] The Aluminum Association, Inc., Washington, D.C., $90019^{\text {th }}$ Street, N.W. (2006) www.aluminum.org

[13] Al-Khazraji, K.K., Moosa, A.A. and Muhammed, O.S., "Microstructure, Density, Hardness and Wear Resistance of Squeeze Cast Graphite Particles Reinforced AluminumSilicon Composites", Proceeding of the first scientific conference on nanotechnology, 
advanced materials and their applications held at the University of Technology, Oct.13-14, Baghdad, Iraq (2009).

[14] ASTM, "Metals Test Method and Analytical Procedure", Vol. 05.02 (1989).

[15] U. N. I. D. O., "Advances in Material Tech.", Monitor Vienna International Center, Austria, pp: 9-11 (1990)

[16] Maleki, A., Niroumand, B. and Shafyei, A., "Effects of squeeze casting parameters on density, macrostructure and hardness of LM13 alloy", Mat. Sci. Eng., A428: 135-140 (2006).

[17] Raji A. and Khan R.H., "Effects of pouring temperature and squeeze pressure on $\mathrm{Al}-8 \% \mathrm{Si}$ alloy squeeze cast parts", $A U J$. T., 9(4): 229-237 (2006).

[18] Sukumaran, K., Ravikumar, K.K., Pillai, S.G.K., Rajan, T.P.D., Ravi, M., Pillai, R.M. and Pai, B.C., "Studies on squeeze casting of Al 2124 alloy and $2124-10 \%$ SiCp metal matrix composite", Materials Science and Engineering A, 490: 235-241(2008).

[19] Franklin, J.R. and Das, A.A., "Squeeze Casting - A Review of the Status", British Foundryman Journal, 77: 150-158 (1984). 


\section{دراسة تأثير ضغط السباكة على مقاومة البلي لسبيكة الألومنيوم - سليكون المحضرة بطريقة السباكة بالعصر}

\section{منى خضير عباس، و أسامة سلطان محمد}

قسم هندسة الإنتاج والدعادن وقسم هندسة الدواد، الجامعة التكنولوجية

$$
\text { بغداد- العراق }
$$

المستخلص. في هذا البحث تم دراسة تاثير ضغط السباكة المسلط

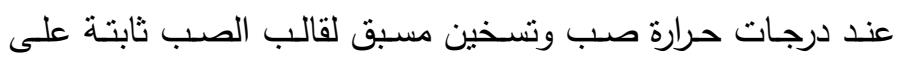
التركيب المجهري ومقاومة تآكل البلي لسبيكة الألومنيوم - سليكون

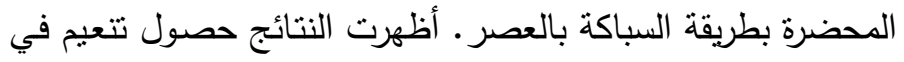

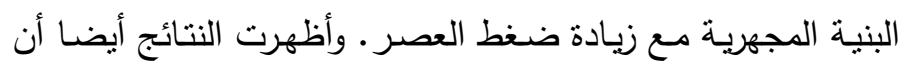
كثافة العينات قد قلت عند تطبيق ضغط مسلط مقداره (7.5MPa)،

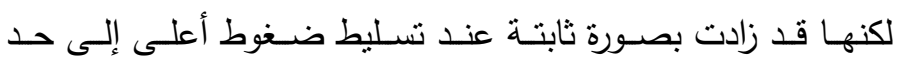

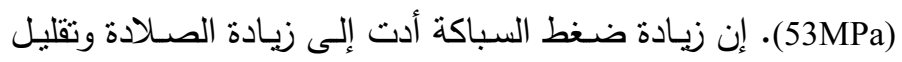

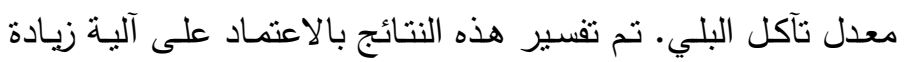
الكثافة الناتجة بواسطة تطبيق الضغط أثناء التجمد. 